Article

\title{
Protective Effect of Curcumin against Sodium Salicylate-Induced Oxidative Kidney Damage, Nuclear Factor-Kappa Dysregulation, and Apoptotic Consequences in Rats
}

\author{
Yasmina M. Abd-Elhakim ${ }^{1, * \mathbb{C}}$, Attia A. A. Moselhy ${ }^{2}$, Adil Aldhahrani ${ }^{3}$, Rasha R. Beheiry ${ }^{4}$, \\ Wafaa A. M. Mohamed ${ }^{5}$, Mohamed Mohamed Soliman ${ }^{3}{ }^{(1)}$, Bayan A. Saffaf ${ }^{6}$ and Maha M. El Deib ${ }^{7}(\mathbb{D}$
}

check for updates

Citation: Abd-Elhakim, Y.M.; Moselhy, A.A.A.; Aldhahrani, A.; Beheiry, R.R.; Mohamed, W.A.M.; Soliman, M.M.; Saffaf, B.A.; M. El Deib, M. Protective Effect of Curcumin against Sodium Salicylate-Induced Oxidative Kidney Damage, Nuclear Factor-Kappa Dysregulation, and Apoptotic Consequences in Rats. Antioxidants 2021, 10, 826. https://doi.org/ $10.3390 /$ antiox 10060826

Academic Editors: Natalia Di Pietro and Mario Bonomini

Received: 24 April 2021

Accepted: 17 May 2021

Published: 21 May 2021

Publisher's Note: MDPI stays neutral with regard to jurisdictional claims in published maps and institutional affiliations.

Copyright: (c) 2021 by the authors. Licensee MDPI, Basel, Switzerland. This article is an open access article distributed under the terms and conditions of the Creative Commons Attribution (CC BY) license (https:// creativecommons.org/licenses/by/ $4.0 /)$.
1 Department of Forensic Medicine and Toxicology, Faculty of Veterinary Medicine, Zagazig University, Zagazig 44519, Egypt

2 Department of Anatomy and Embryology, Faculty of Veterinary Medicine, Zagazig University, Zagazig 44519, Egypt; atiaanatomy@gmail.com

3 Clinical Laboratory Sciences Department, Turabah University College, Taif University, Turabah 21995, Saudi Arabia; a.ahdhahrani@tu.edu.sa (A.A.); mmsoliman@tu.edu.sa (M.M.S.)

4 Department of Histology and Cytology, Faculty of Veterinary Medicine, Zagazig University, Zagazig 44519, Egypt; rasharagab2006@yahoo.com

5 Department of Clinical Pathology, Faculty of Veterinary Medicine, Zagazig University, Zagazig 44519, Egypt; waffa.clinical@yahoo.com

6 Pharmacology Department, Faculty of Pharmacy, Future University, City of the Future 41639, Egypt; Bayan.saffaf@fue.edu.eg

7 Department of Biochemistry, Faculty of Veterinary Medicine, Zagazig University, Zagazig 44519, Egypt; dr.mmeldeib@yahoo.com

* Correspondence: yasminafor@zu.edu.eg; Fax: +20-55-228-4283

\begin{abstract}
This study examined the effect of sodium salicylates (SS), alone and in combination with curcumin (CUR), on kidney function and architecture in rats. Five rat groups were given $1 \mathrm{~mL}$ physiological saline/rat orally, $1 \mathrm{~mL}$ olive oil/rat orally, $50 \mathrm{mg}$ CUR/kg bwt orally, $300 \mathrm{mg}$ $\mathrm{SS} / \mathrm{kg}$ bwt intraperitoneally, or CUR+SS for 15 days. The hematological indices, serum protein profile, serum electrolytes balance, oxidative stress, and lipid peroxidation of kidney tissues were assessed. The histopathological examination and immune expression of Caspase- 3 and nuclear factor kappa (NF- $\mathrm{KB}$ ) were conducted. The findings showed that SS injection induced nephrotoxic activity, including increased serum urea, creatinine, and uric acid levels. It also caused apparent pathological alterations with increased Caspase-3 and NF- $\mathrm{kB}$ immuno-expression. In addition, thrombocytopenia, leukocytosis, neutrophilia, hyponatremia, hypochloremia, hypocalcemia, and hypomagnesemia but not hyperkalemia and hyperphosphatemia were evident in SS-injected rats. Moreover, SS exposure increased serum $\alpha 1$ globulin, renal tissue malondialdehyde, and Caspase- 3 levels but superoxide dismutase, glutathione peroxidase, and Bcl-2 levels declined. Meanwhile, CUR significantly counteracted the SS harmful impacts on kidneys but SS+CUR co-administration induced an anemic condition. Overall, CUR has an evident protective role against SS-induced renal damage, but the disturbed hematological alterations should be carefully taken into consideration in their combined use.
\end{abstract}

Keywords: curcumin; sodium salicylate; kidney; anemia; NF-kappa B; Caspase-3

\section{Introduction}

Sodium salicylate (SS) is commonly prescribed as an anti-inflammatory and pain relief drug [1]. Despite the important therapeutic roles of SS, several complications have been reported to be associated with SS overdose, including tinnitus [2], hearing loss [3], and neurotoxicity [4]. Furthermore, a high single salicylates dose in rats led to increased urinary levels 
of enzymes coming from proximal tubular cells. These results were often linked to biochemical indices of proximal tubular dysfunction such as potassium wastage and glucosuria $[5,6]$. In most cases, proximal tubular dysfunction caused by salicylate occurred within several hours of administration and rarely lasted longer than several days. Morphological deviations associated with compromised tubular function ranged from mild to deep proximal tubular necrosis with the extension of nuclear pyknosis and karyolysis and with proximal membrane degeneration. Tubular epithelial regeneration was not observed until $24 \mathrm{~h}$ following treatment [7]. Additionally, deliberate ingestion or unintentional overdose of SS can result in severe metabolic derangements, making treatment challenging. Moreover, co-ingestion of other medications can further complicate management [8]. Therefore, complementary medicinal products can be a worthwhile approach to address the above challenges, adding to SS effectiveness while masking toxicity [9].

In recent years, several natural products showed strong nephroprotective activity [10-13]. Curcumin (CUR), the Curcuma longa Linn yellow pigment, has attracted much attention for medicinal purposes in a wide range of illnesses such as autoimmune diseases [14], cancer [15], diabetes mellitus [16], and fatty liver disease [17,18]. CUR has a potent antioxidant $[19,20]$, anti-inflammatory [14], antiproliferative [21,22], immunostimulant [23], and neuroprotective activities [4,24]. In addition, several recent reports have confirmed the protective role of CUR against drug-induced nephrotoxicity [25-27]. Recently, Mohapatra, et al. [9] developed a co-amorphous mixture of acetylsalicylic acid and CUR for improving dissolution, enhancing anti-inflammatory activity, and diminishing gastro toxicity. They confirmed that this low-dose combination could be a successful approach for anti-inflammation combination therapy. On the other hand, some reports spotlighted the dark aspects of CUR, particularly in combination with certain medications or drugs [28]. For instance, Khalaji, et al. [29] reported that the combined use of CUR with a derivative of amphetamine named ecstasy induced serious consequences on hematological parameters and serum immunoglobin levels.

CUR showed nephroprotective effects when orally dosed at $50 \mathrm{mg} / \mathrm{kg}$ bwt against xenobiotic-inducing kidney damage [30-32]. Hence, in the current study, we explored the outcomes of CUR (50 mg/ $\mathrm{kg}$ bwt) co-treatment with large doses of SS (300 mg/kg bwt) on blood cells and kidney function. For this purpose, rats were given CUR and/or SS for 15 days and then exposed to hematological, biochemical, histopathological, and immunohistochemical evaluations.

\section{Materials and Methods}

\subsection{Tested Compounds and Chemicals}

SS from El Nasr pharmaceutical chemicals "Adwic", Cairo, Egypt, was used. A stock solution of CUR was prepared using olive oil (Colavita via laurentina", Rome, Italy). All other chemicals were purchased from Sigma-Aldrich Co., St. Louis, MO, USA.

\subsection{Animals and Experimental Design}

Fifty healthy Sprague Dawley rats (male, 140-160 g, 10 weeks of age) were attained from the Laboratory Animal Housing Unit, Faculty of Veterinary Medicine, Zagazig University, Egypt. In a $12 \mathrm{~h}$ light/12 h dark, rats are kept in a stainless steel cage with free, accessible food and water in a well-ventilated room. Two weeks before any experimental studies were carried out, the experimental animals were acclimated to laboratory conditions. Randomly five groups (10 rats/treatment) were divided between the experimental group and control: control, orally administered $1 \mathrm{~mL}$ of saline / rat; olive oil group (OO), orally given $1 \mathrm{~mL}$ of olive oil/rat; CUR group, orally given $50 \mathrm{mg}$ of CUR / $\mathrm{kg}$ bwt [33]; SS group, intraperitoneally injected a dose of $300 \mathrm{mg} / \mathrm{kg}$ bwt of SS in bacteriostatic saline $60 \mathrm{mg} / \mathrm{mL}$ once daily [34]; and CUR+SS group, CUR and SS were administered at the doses and routes mentioned above. The experiment continued for 15 days, as several documented case studies showed various side effects in patients who consumed SS up to 15 successive days [35]. Additionally, in this context, Yi, et al. [36] assessed the SS side 
effects when orally administered at a dose of $200 \mathrm{mg} / \mathrm{kg}$ bwt for 14 consecutive days. The pain, injury, abnormal behavior, distress, mucous membranes, breathing patterns, morbidity, and mortality during the experiment were closely monitored.

\subsection{Sampling}

At the end of the experiment, the rats were anesthetized and then euthanized by decapitation. Blood samples were collected from the retro-orbital plexus. For hematological analysis, the samples were collected in tubes with EDTA $10 \%$ as an anticoagulant. The other samples were taken in plain tubes and were left to clot for $30 \mathrm{~min}$ at room temperature. Then, the samples were centrifuged at $3000 \mathrm{rpm}$ for $20 \mathrm{~min}$. The resultant serum was stored at $-20{ }^{\circ} \mathrm{C}$ until analysis. The kidneys were removed, saline-washed, weighed, and then divided into two groups of specimens. The first group was homogenized and centrifuged at $664 \times \mathrm{g}$ for $15 \mathrm{~min}$ at $4{ }^{\circ} \mathrm{C}$, and the resultant supernatants were used in the biochemical indicator estimation. For histopathological and immunohistopathological examinations, the second group was stored in $10 \%$ neutral buffered formalin.

\subsection{Hematological Analysis}

Complete blood counts, including leukogram and erythrogram profiles, were measured using an automated blood cell analyzer (Hemascreen18, Hospitex diagnostics, Sesto Fiorentino, Italy).

\subsection{Serum Biochemical Analysis}

\subsubsection{Measurement of Some Kidney Function Tests}

The protocols by Coulombe and Favreau [37], and Larsen [38] were used to assess the serum levels of urea and creatinine, respectively. The concentration of uric acid was estimated using the technique by Barham and Trinder [39]. The potassium tetraphenylborate gravimetric method without deproteinization [40] and the single reagent method [41] were used to detect potassium $(\mathrm{K})$ and sodium $(\mathrm{Na})$ amounts, respectively. Magnesium $(\mathrm{Mg})$, calcium $(\mathrm{Ca})$, chloride $(\mathrm{Cl})$, and phosphorous $(\mathrm{Ph})$ were determined colorimetrically using bio-diagnostic kits (Giza, Egypt) following the methods of Tietz [42], Gindler and King [43], Schales and Schales [44], and El-Merzabani and El-Aaser [45], respectively.

\subsubsection{Protein Profile}

The total level of serum protein was estimated according to the method of Gornal, et al. [46]. Based on the technique of Doumas, et al. [47], serum albumin concentration was evaluated. By subtracting the albumin amount from the total protein amount, total amount of globulin was calculated [48]. Serum protein fractionation was performed using sodium sulfate-polyacrylamide gel electrophoresis (SDS-PAGE) technique for the determination of serum alpha $(\alpha)$, beta $(\beta)$, and gamma $(G)$ globulins according to the method illustrated by Ornstein [49].

\subsection{Assessment of Oxidative Stress and Apoptotic Parameters in Kidney Tissue}

The methods applied by Nishikimi, et al. [50] and by Paglia and Valentine [51] were used for the evaluation of superoxide dismutase (SOD) and glutathione peroxidase (GPx), respectively, using commercial colorimetric bioassay kits (Biodiagnostic Co. Dokki, Giza, Egypt). A lipid peroxidation biomarker, malondialdehyde (MDA) content, was measured by the Ohkawa, et al. [52] method.

Rat ELISA kits were used to detect apoptotic indicators in the kidney tissue, comprising Caspase-3 and Bcl-2. The kits were obtained from MyBioSource (San Diego, CA, USA) (catalog No. MBS700575 and MBS2515143) for Caspase-3 and Bcl-2, respectively. The quantification was carried out in triples according to the instructions of the manufacturer. 


\subsection{Histopathological Investigations}

The collected kidney tissue specimens were kept for $48 \mathrm{~h}$ in $10 \%$ neutral buffered formalin. Then, formalin-fixed specimens were dehydrated in graded ethanol (70-100\%), cleaned with xylene for one hour two times, and embedded in paraffin. The paraffinized blocks were then divided into 5 micron sections and stained with hematoxylin and eosin [53].

\subsection{Immunohistochemical Investigation of Caspase-3 and NF- $\kappa B$ Activity in the Kidney Tissues}

Another set of kidney paraffin sections was used for Caspase-3 detection by a rabbit polyclonal antibody (cat no: RB-1197-R7 Thermo Fisher Scientific, Waltham, MA, USA). For NF- $\mathrm{kB}$ investigation, some kidney paraffin sections were used, stained for NF- $\mathrm{kB}$ by rabbit polyclonal NF-kB p65 (phospho S276) primary antibody (ab194726), goat antirabbit IgG H\&L (HRP) secondary antibody (ab205718) (Abcam, Cambridge, UK), and $3,3^{\prime}$-diaminobenzidine chromogen in line with the ABC method [54]

\subsection{Data Analysis}

The computer program SPSS/PC +2001 was used for statistical analysis of the study data. The statistical method used was one-way ANOVA and Dunnett's multiple comparison test. The data are displayed as mean $\pm \mathrm{SD}$. A minimum significance level of $p<0.05$ was set.

\section{Results}

\subsection{Effects on Relative Kidney Weights and Hematological Indicators}

As shown in Table 1, no significant differences were recorded in the right or left relative kidney weights among the different experimental groups. Neither the individual SS injection nor the oral CUR doses alter the erythrogram elements compared to the control groups. However, the combined SS+CUR administration significantly $(p<0.001)$ reduced the $\mathrm{RBC}$ count, $\mathrm{Hb}$ content, $\mathrm{PCV} \%$, and $\mathrm{MCH}$ compared to the other experimental groups. However, no significant changes in MCV and MCHC were recorded among different experimental groups. Alternatively, a significant $(p<0.001)$ decline in the platelet count was recorded in the SS-injected rats compared to the control group. Conversely, the CUR and CUR+SS-treated groups showed a significant increase in the platelet count compared to the SS-injected and control groups.

Table 1. Effect of curcumin (CUR) treatment on hematological indices of sodium salicylate (SS)-administered rats for 15 days.

\begin{tabular}{cccccc}
\hline Parameters & Control & OO & CUR & SS & CUR+SS \\
\hline Relative right kidney weight & $0.40 \pm 0.04$ & $0.51 \pm 0.04$ & $0.46 \pm 0.05$ & $0.41 \pm 0.10$ & $0.42 \pm 0.10$ \\
Left relative kidney weight & $0.44 \pm 0.01$ & $0.48 \pm 0.03$ & $0.48 \pm 0.08$ & $0.44 \pm 0.09$ & $0.44 \pm 0.01$ \\
Erythrogram & & & & \\
RBCs $\left(10^{6} / \mathrm{mm}^{3}\right)$ & $4.35 \pm 0.23$ & $4.41 \pm 0.65$ & $4.53 \pm 0.30$ & $4.40 \pm 0.47$ & $2.67 * \# \pm .04$ \\
$\mathrm{Hb}(\mathrm{g} / \mathrm{dL})$ & $10.87 \pm 0.12$ & $11.47 \pm 1.10$ & $11.73 \pm 1.47$ & $10.23 \pm 1.41$ & $7.20^{* \#} \pm 0.14$ \\
$\mathrm{PCV}(\%)$ & $23.07 \pm 3.36$ & $22.73 \pm 2.82$ & $24.87 \pm 2.98$ & $24.47 \pm 3.31$ & $14.23 * \pm 0.34$ \\
$\mathrm{MCV}(\mathrm{fl})$ & $52.93 \pm 1.89$ & $52.97 \pm 1.54$ & $55.40 \pm 0.51$ & $55.47 \pm 3.14$ & $54.07 \pm 0.95$ \\
$\mathrm{MCH}(\%)$ & $26.63 \pm 0.58$ & $26.70 \pm 1.42$ & $25.90 \pm 2.01$ & $23.23^{*} \pm 1.00$ & $27.37^{\#} \pm 0.37$ \\
$\mathrm{MCHC}(\%)$ & $45.63 \pm 2.95$ & $47.57 \pm 2.40$ & $43.23 \pm 1.84$ & $45.23 \pm 3.87$ & $47.93 \pm 3.69$ \\
Platelets $\left(10^{3} / \mathrm{mm}^{3}\right)$ & $314.33 \pm 23.33$ & $315.33 \pm 53.94$ & $565.00 * \# \pm 134.35$ & $376.67 * \pm 8.81$ & $534.67 * \# \pm 66.78$ \\
Leukogram & & & & \\
WBCs $\left(10^{3} / \mathrm{mm}^{3}\right)$ & $5.10 \pm 0.22$ & $5.33 \pm 0.21$ & $5.37 \pm 0.56$ & $9.40^{*} \pm 0.22$ & 5.23 \# \pm 0.53 \\
Neutrophils $\left(10^{3} / \mathrm{mm}^{3}\right)$ & $19.00 \pm 2.45$ & $19.00 \pm 2.16$ & $18.67 \pm 2.05$ & $24.67 * \pm 3.30$ & $19.00^{*} \pm 4.55$ \\
Lymphocytes $\left(10^{3} / \mathrm{mm}^{3}\right)$ & $69.33 \pm 3.86$ & $67.00 \pm 2.94$ & $69.67 \pm 5.73$ & $69.33 \pm 4.03$ & $68.67 \pm 6.34$ \\
Eosinophils $\left(10^{3} / \mathrm{mm}^{3}\right)$ & $1.00 \pm 0.00$ & $1.33 \pm 0.47$ & $1.33 \pm 0.47$ & $1.33 \pm 0.47$ & $1.00 \pm 0.00$ \\
Monocytes $\left(10^{3} / \mathrm{mm}^{3}\right)$ & $11.67 \pm 1.25$ & $13.33 \pm 2.05$ & $12.67 \pm 2.49$ & $11.33 \pm 1.25$ & $13.00 \pm 0.82$ \\
Basophils $\left(10^{3} / \mathrm{mm}^{3}\right)$ & $0.00 \pm 0.00$ & $0.00 \pm 0.00$ & $0.00 \pm 0.00$ & $0.00 \pm 0.00$ & $0.00 \pm 0.00$ \\
\hline
\end{tabular}

OO: olive oil. Values are represented as the mean \pm SD. $n=10$ replicates/treatment. ${ }^{*}$ Significantly different compared to the control groups at $p<0.05$. " Significantly different from the SS-treated group at $p<0.05$. 
Regarding the leukogram, the SS-injected group displayed a significant increase in the WBCs $(p<0.001)$ and neutrophil $(p=0.061)$ counts relative to the control groups. In contrast, the CUR oral dose significantly suppressed the SS-induced increments in the number of WBCs and neutrophils compared to the SS-injected groups to a level nonsignificantly different from the control group. Nonetheless, no significant changes in the counts of lymphocytes, monocytes, eosinophils, and basophils were found among the diverse experimental groups.

\subsection{Effects on Protein Fractions}

The influence of a CUR oral dose for 15 days and/or SS intraperitoneal injection in rats on protein profile is revealed in Table 2. The SS-injected rats showed a significant $(p<0.001)$ reduction in the total protein, albumin, total globulin, and $\gamma$ globulin by $34.91 \%$, $43.44 \%, 24.63 \%$, and $55.47 \%$ relative to the control group. However, a significant $(p<0.001)$ increase in $\alpha 2$ glob was found in the SS-injected rats by $34.19 \%$ compared to the control group. On the other hand, SS-induced depletion in the level of total protein, albumin, total globulin, and $\gamma$ globulin was restored less than the control group by $20.68 \%, 24.75 \%$, $15.78 \%$, and $35.94 \%$, respectively, when combined with CUR oral administration.

Table 2. Effect of curcumin (CUR) treatment on biochemical indicators of sodium salicylate (SS) administered rats for 15 days.

\begin{tabular}{|c|c|c|c|c|c|}
\hline Parameters & Control & OO & CUR & SS & CUR+SS \\
\hline Total protein $(\mathrm{g} / \mathrm{L})$ & $74.70 \pm 3.18$ & $75.23 \pm 2.54$ & $74.85 \pm 2.96$ & $48.63 * \pm 4.86$ & $59.25^{* \#} \pm 0.99$ \\
\hline Albumin (g/L) & $40.80 \pm 1.06$ & $41.05 \pm 1.51$ & $41.28 \pm 1.15$ & $23.08^{*} \pm 2.88$ & $30.70 * \#+3.10$ \\
\hline Total globulin (g/L) & $33.90 \pm 3.64$ & $34.18 \pm 3.12$ & $33.58 \pm 3.61$ & $25.55 * \pm 5.03$ & $28.55 \pm 3.00$ \\
\hline$\alpha 1$ globulin $(\mathrm{g} / \mathrm{L})$ & $18.98 \pm 3.68$ & $19.30 \pm 3.45$ & $18.40 \pm 3.81$ & $13.03 \pm 6.30$ & $13.45 \pm 3.65$ \\
\hline$\alpha 2$ globulin $(\mathrm{g} / \mathrm{L})$ & $6.78 \pm 0.21$ & $6.73 \pm 0.45$ & $6.90 \pm 0.29$ & $9.13 * \pm 0.57$ & $8.20 * \# \pm 0.34$ \\
\hline$\beta$ globulin $(\mathrm{g} / \mathrm{L})$ & $4.97 \pm 0.34$ & $5.06 \pm 0.33$ & $5.04 \pm 0.12$ & $4.82 \pm 0.57$ & $4.99 \pm 0.67$ \\
\hline$\gamma$ globulin $(\mathrm{g} / \mathrm{L})$ & $3.20 \pm 0.54$ & $3.08 \pm 0.33$ & $3.26 \pm 0.46$ & $1.42 * \pm 0.38$ & $2.05^{* \#} \pm 0.17$ \\
\hline Urea (mmol/L) & $9.17 \pm 1.61$ & $9.39 \pm 0.89$ & $9.40 \pm 1.38$ & $16.77^{*} \pm 1.77$ & $13.57^{* \#} \pm 0.77$ \\
\hline Creatinine (umol/L) & $72.33 \pm 2.17$ & $72.69 \pm 3.43$ & $72.26 \pm 1.88$ & $107.83 * \pm 7.94$ & $90.85^{* \#} \pm 3.42$ \\
\hline Uric acid (umol/L) & $354.70 \pm 9.12$ & $355.63 \pm 9.56$ & $355.49 \pm 13.00$ & $727.24 * \pm 59.80$ & $544.90^{* \#} \pm 14.89$ \\
\hline Sodium (mmol/L) & $144.33 \pm 5.56$ & $140.58 \pm 7.15$ & $144.15 \pm 11.12$ & $93.66^{*} \pm 8.03$ & $120.54^{* \#} \pm 7.39$ \\
\hline Potassium (mmol/L) & $3.93 \pm 0.57$ & $4.53 \pm 0.55$ & $4.28 \pm 0.70$ & $9.80 * \pm 1.14$ & $6.89^{* \#} \pm 0.85$ \\
\hline Chloride (mmol/L) & $91.67 \pm 7.04$ & $93.23 \pm 4.93$ & $94.87 \pm 6.54$ & $65.91 * \pm 5.02$ & $84.16^{\#} \pm 6.69$ \\
\hline Phosphate (mmol/L) & $0.87 \pm 0.02$ & $0.85 \pm 0.03$ & $0.86 \pm 0.05$ & $1.71 * \pm 0.15$ & $1.15^{* \#} \pm 0.11$ \\
\hline Calcium $(\mathrm{mmol} / \mathrm{L})$ & $2.46 \pm 0.20$ & $2.40 \pm 0.20$ & $2.46 \pm 0.11$ & $1.14 * \pm 0.19$ & $1.68^{* \#} \pm 0.07$ \\
\hline Magnesium (mmol/L) & $1.03 \pm 0.07$ & $1.03 \pm 0.04$ & $1.03 \pm 0.07$ & $0.56^{*} \pm 0.07$ & $0.81^{* \#} \pm 0.04$ \\
\hline
\end{tabular}

OO: olive oil. The values are represented as the mean \pm SD. $n=10$ replicates/treatment. * Significantly different compared to the control groups at $p<0.05$. \# Significantly different from the SS-treated group at $p<0.05$.

Moreover, the SS-induced increment in $\alpha 2$ glob amount was minimized with a concurrent CUR oral dose to $20.59 \%$ relative to the control group. Nevertheless, no significant alteration in the concentrations of $\alpha 1$ and $\beta$ globulins was detected among different experimental groups.

\subsection{Effects on Kidney Function Indicators}

As demonstrated in Table 2, a significant $(p<0.001)$ increase in the level of kidney damage including urea, creatinine, and uric acid by $82.92 \%, 48.75 \%$, and $105.16 \%$, respectively, was recorded in the SS-injected rats relative to the control group. However, the CUR oral dose in SS-injected rats significantly depressed the urea, creatinine, and uric acid increments to $47.99 \%, 25.30 \%$, and $53.69 \%$, respectively.

\subsection{Effects on Serum Electrolytes Levels}

As revealed in Table 2, SS-injected rats showed a noticeable disturbance in the electrolyte balance, as demonstrated by a significant $(p<0.001)$ reduction in the levels of $\mathrm{Na}$, 
$\mathrm{Cl}, \mathrm{Ca}$, and $\mathrm{Mg}$ by $35.11 \%, 28.11 \%, 53.57 \%$, and $46.10 \%$, respectively, relative to the control group. In contrast, a significant $(p<0.001)$ increment in the $\mathrm{K}$ and $\mathrm{Ph}$ was recorded in the SS-injected group by $149.36 \%$ and $95.98 \%$, respectively, relative to the control group. Contrariwise, the CUR+SS treated group showed a significant correction of electrolyte levels relative to the SS-injected group.

\subsection{Effects on Oxidative Kidney Damage}

A significant $(p<0.001)$ exhaustion of SOD and GPx enzymes by $48.01 \%$ and $38.17 \%$, respectively, but a significant elevation of MDA (twofold) were recorded in SS-injected rats relative to the control group (Figure 1). On the contrary, the SOD and GPx level in the CUR+SS-treated group was re-established at $20.65 \%$ and $20.68 \%$, respectively, less than the control group. Furthermore, CUR significantly counteracted the SS-induced increase in the MDA content to one-fold in the CUR+SS-treated group more than the control group.
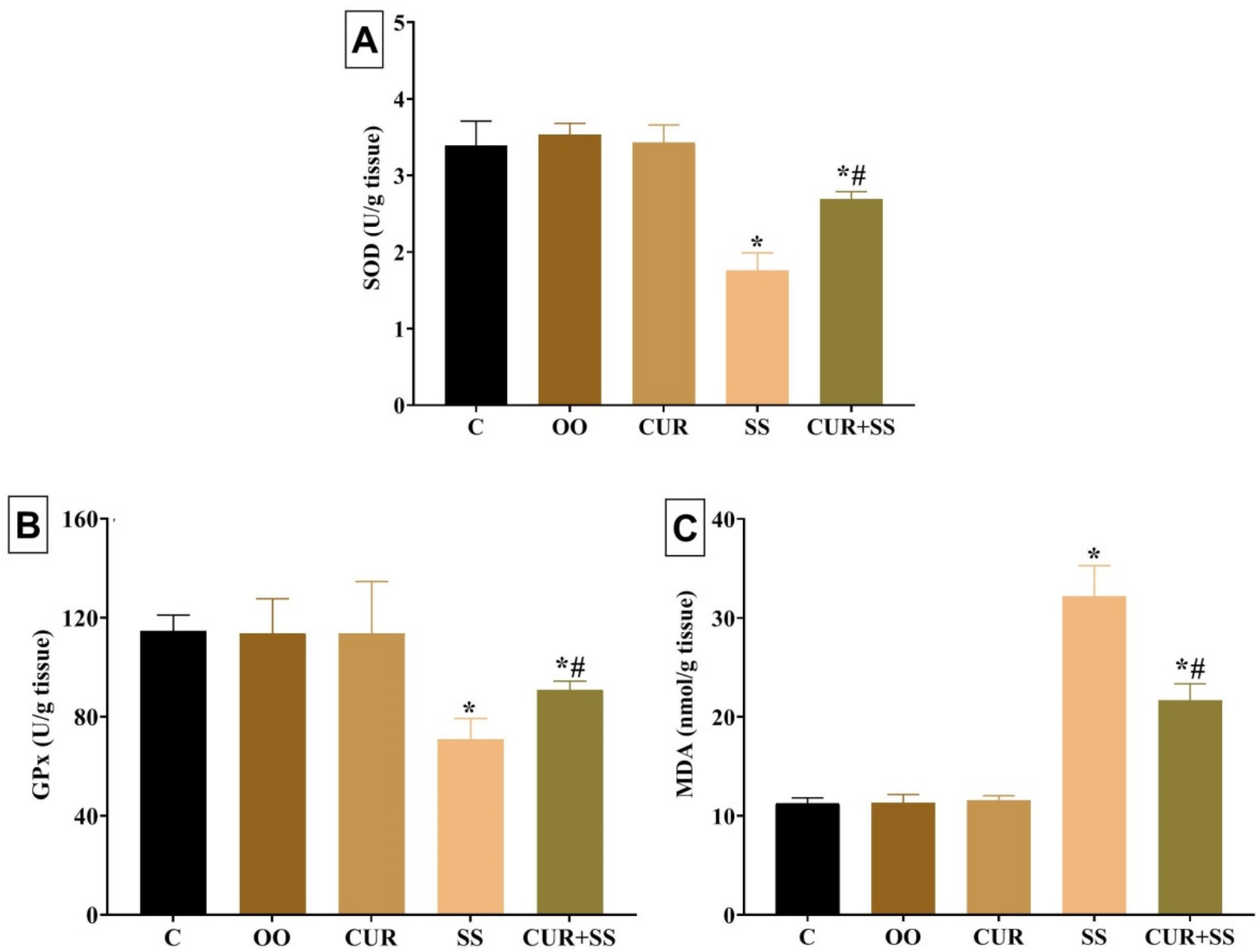

Figure 1. Effect of curcumin (CUR) oral dose on (A) superoxide dismutase (SOD), (B) glutathione peroxidase (GPx), and (C) malondialdehyde (MDA) in the kidney tissues of sodium salicylate (SS)-injected rats for 15 days. C: control group. OO: olive oil. Data are expressed as mean $\pm \mathrm{SD}, n=10$ for each group. * Significantly different compared to the control groups at $p<0.05 .{ }^{\#}$ Significantly different from the SS-treated group at $p<0.05$.

\subsection{Effects on Apoptotic Indicators in Kidney Tissues}

As revealed in Figure 2, the apoptotic protein level of Caspase-3 was significantly $(p<0.001)$ augmented by $87.51 \%$ in SS-injected rats relative to the control group. Nonetheless, compared to the control group, SS injection for 15 days resulted in a significant $(p<0.001)$ decrease $(59.86 \%)$ in the antiapoptotic protein Bcl-2. In the CUR+SS group, the SS-induced expression of the apoptotic protein Caspase- 3 was reduced to $49.07 \%$ compared 
to the control group. Moreover, the SS-induced decline in the Bcl-2 level was restored by a CUR oral dose to $36.81 \%$ in the CUR+SS-treated group compared to the control group.
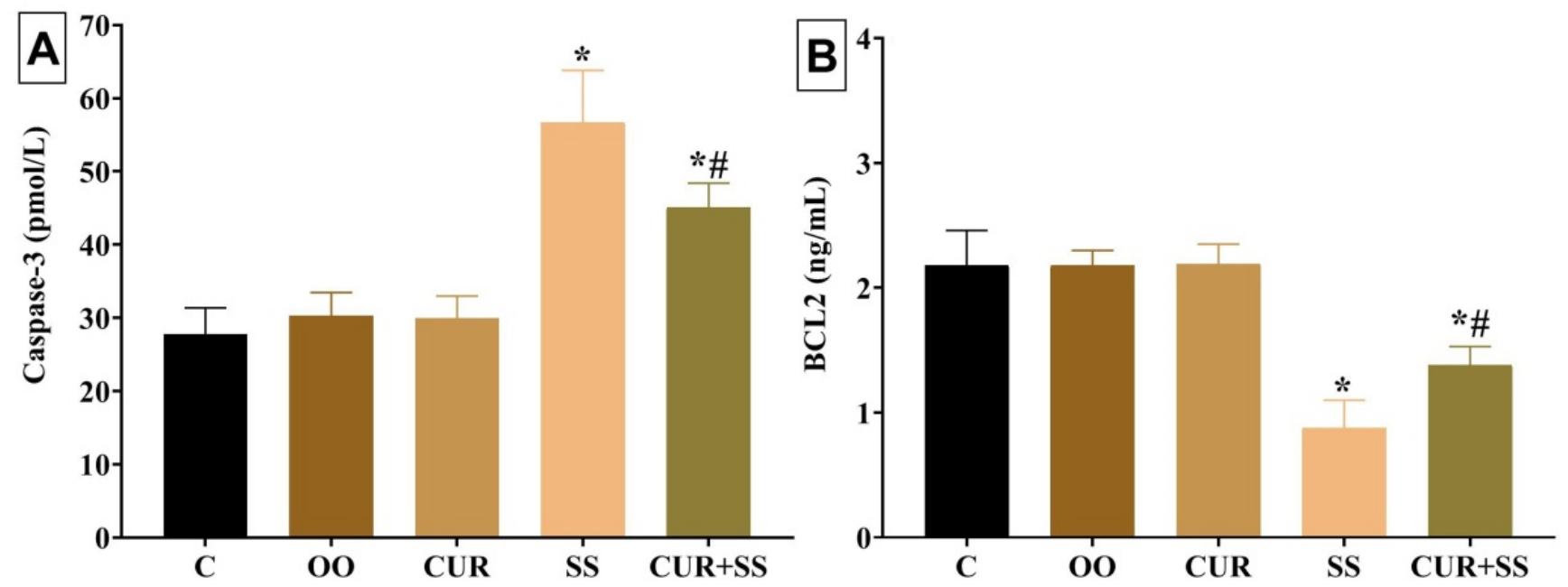

Figure 2. Effect of curcumin (CUR) oral dose on Caspase-3 (A) and BCL-2 (B) in the kidney tissues of sodium salicylate (SS)-injected rats for 15 days. C: control group. OO: olive oil. Data are expressed as mean \pm SD, $n=10$ for each group. * Significantly different compared to the control groups at $p<0.05$. \# Significantly different from the SS-treated group at $p<0.05$.

\subsection{Histopathological Findings}

Histological observations of the kidney of control and CUR-treated rats showed that the normal corpuscles formed from the outer and inner Bowman's capsule, glomerulus and capsular space, and normal renal tubules. The SS-treated rats' kidneys revealed degenerative changes in the renal tubules, vascular congestion, and severe glomerular congestion. The absence of the capsular space with severe congestion of the peritubular capillaries was noticed. Moreover, coagulative necrosis of some renal tubules and other structures showed tubular dilation. Some renal glomeruli showed shrinkage of their glomerular tuft or an absence with widening of the capsular space. Vacuolation in the epithelial lining of some renal tubules was observed. In the SS+CUR group, the changes were decreased compared with the sodium salicylate-treated rats. The most apparent lesions were vascular congestion and mild epithelial vacuolation, and some renal tubules showed regenerative attempt (Figure 3).

\subsection{Immunohistochemical Findings}

Immunohistochemical examination of Caspase-3 immuno-expression in the control and CUR group renal tissue revealed a negative to weak reaction in the renal tubules. At the same time, a dark brown color in the glomeruli was detected (Figure 4). In SS-treated rats, a strong positive reaction was mainly present in the cytoplasm of renal tubules. In the SS+CUR-treated group, decreased Caspase-3 immuno-expression was observed and a dark brown color in the glomeruli was noticed.

The expression of NF- $\mathrm{kB}$ of the control and CUR group renal tissue revealed a weak reaction in the control group and a moderate reaction in the CUR group. In SS-treated rats, a strong positive reaction was detected in the nuclei of renal tubules. In the SS+CUR group, the immuno-expression of NF- $\mathrm{kB}$ decreased compared to the SS-exposed group (Figure 5). 

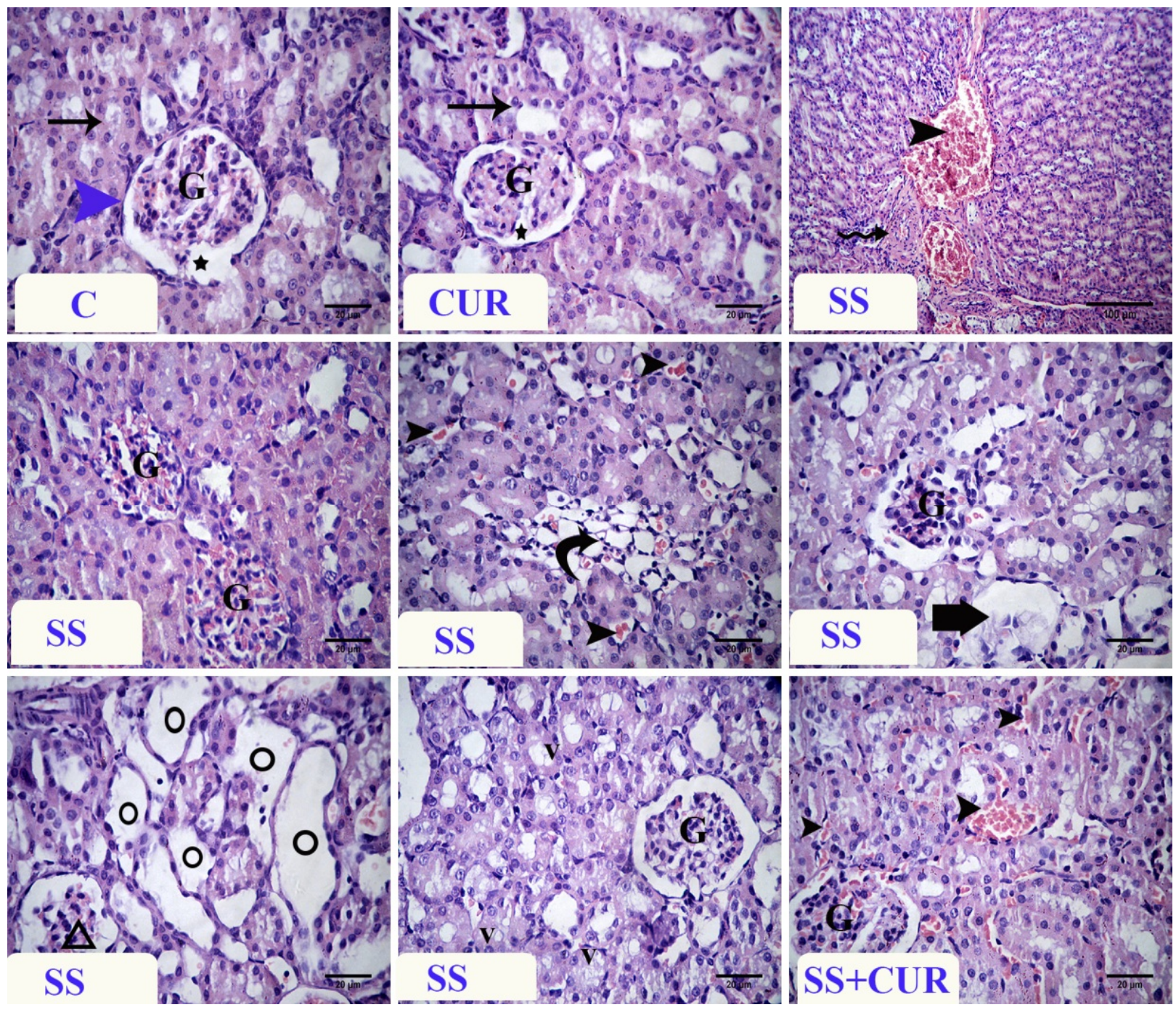

Figure 3. Photomicrograph of H\&E-stained renal tissue sections. Control (C) and curcumin (CUR) group showing the normal glomeruli (G), renal tubules (arrows), outer layer of Bowman's capsule (blue arrowhead), and capsular space (star). Sodium salicylate (SS)-treated group showing vascular congestion (arrowhead) and hyalinization of the blood vessel (zigzag arrow), absence of capsular space and glomerular congestion (G), coagulative necrosis (curved arrow), congestion of peritubular capillaries (arrowheads), absence of glomerular tuft (thick arrow), tubular dilation (circles) shrinkage of the glomerulus (triangle), and vacuolation of the lining epithelium of tubules (v). SS + CUR-treated group showing vascular congestion (arrowheads) and normal glomeruli (G). The magnification was $\times 400$ in all photos, except the first one of SS was $\times 100$.

\subsection{Correlation Analysis by Principal Components Analysis}

In this case, the main component analysis tested the relationships between current variables. The first two loading components were outlined as displayed in Figure 6, with nearly $88.52 \%$ of the total variation in the experimental data being recorded. The variables grouped narrowly $\left(<90^{\circ}\right)$ have prominent correlations, and in the loading plot, they have a positive correlation. Subsequently, total protein, magnesium, calcium, albumin, SOD, $\mathrm{Bcl} 2$, sodium, $\gamma$ globulin, chloride, Gpx, and globulin were grouped together and strongly correlated with the first component. These collections were greatly negatively associated with uric acid, MDA, creatinine, phosphate, potassium, caspase3, urea, and $\alpha 2$ globulin. 


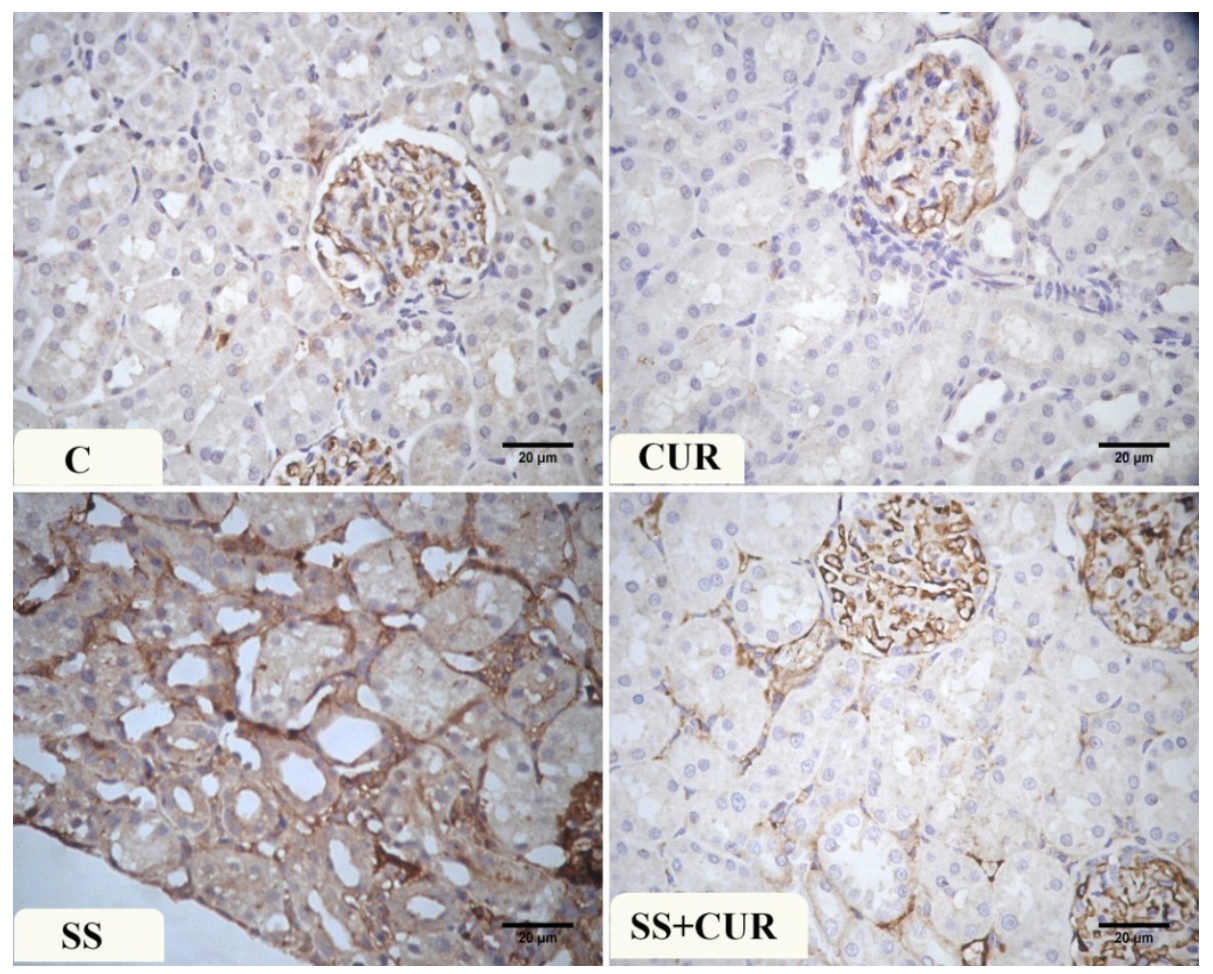

Figure 4. Photomicrograph of the renal tissue sections showing the Caspase -3 immuno-expression in different studied groups: (C) control, (CUR) curcumin, (SS) sodium salicylate, and SS+CUR-treated groups. Magnification $\times 400$.

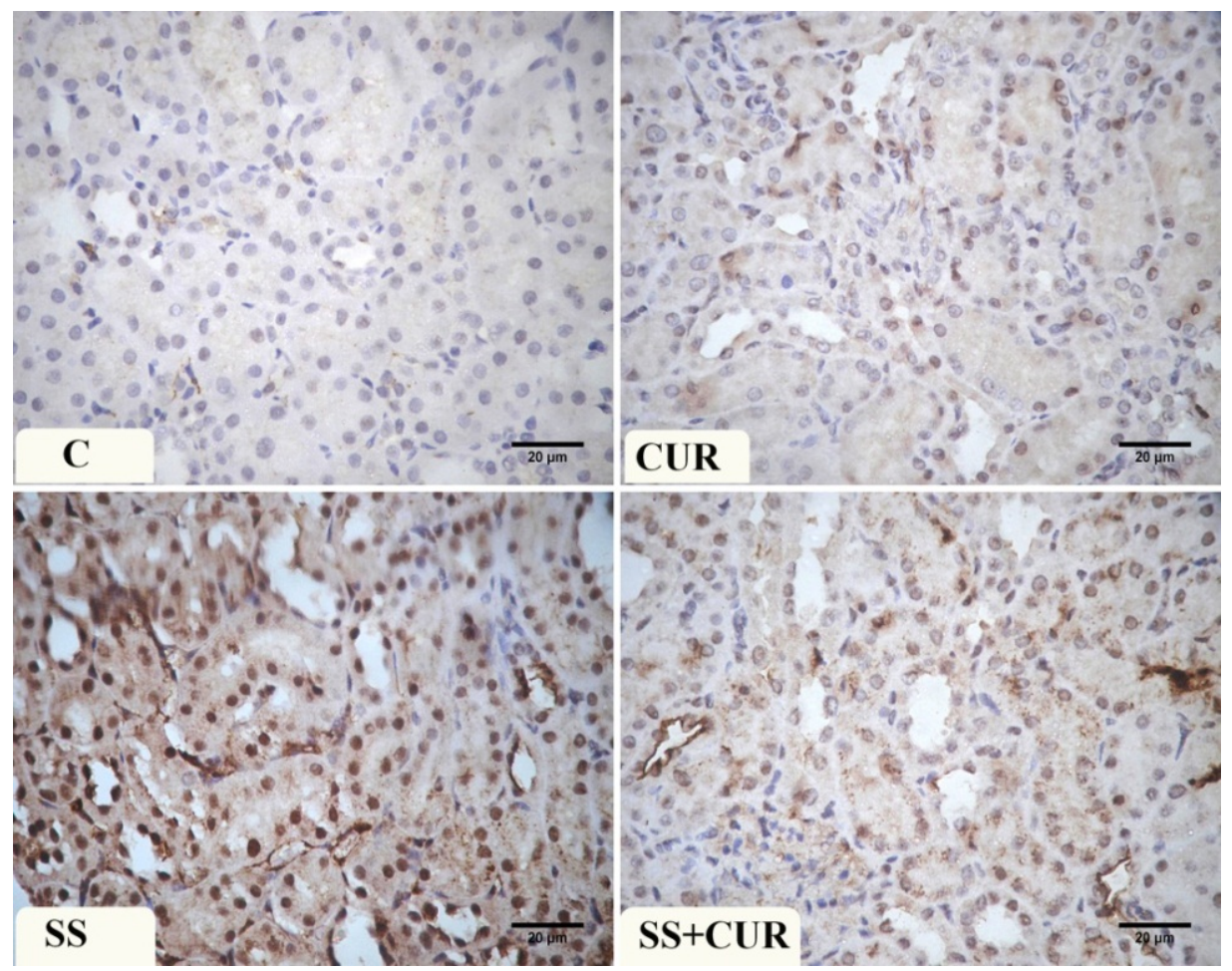

Figure 5. Photomicrograph of the renal tissue sections showing the NF- $\mathrm{kB}$ immuno-expression in different studied groups: (C) control, (CUR) curcumin, (SS) sodium salicylate, and SS+CUR-treated groups. Magnification $\times 400$. 

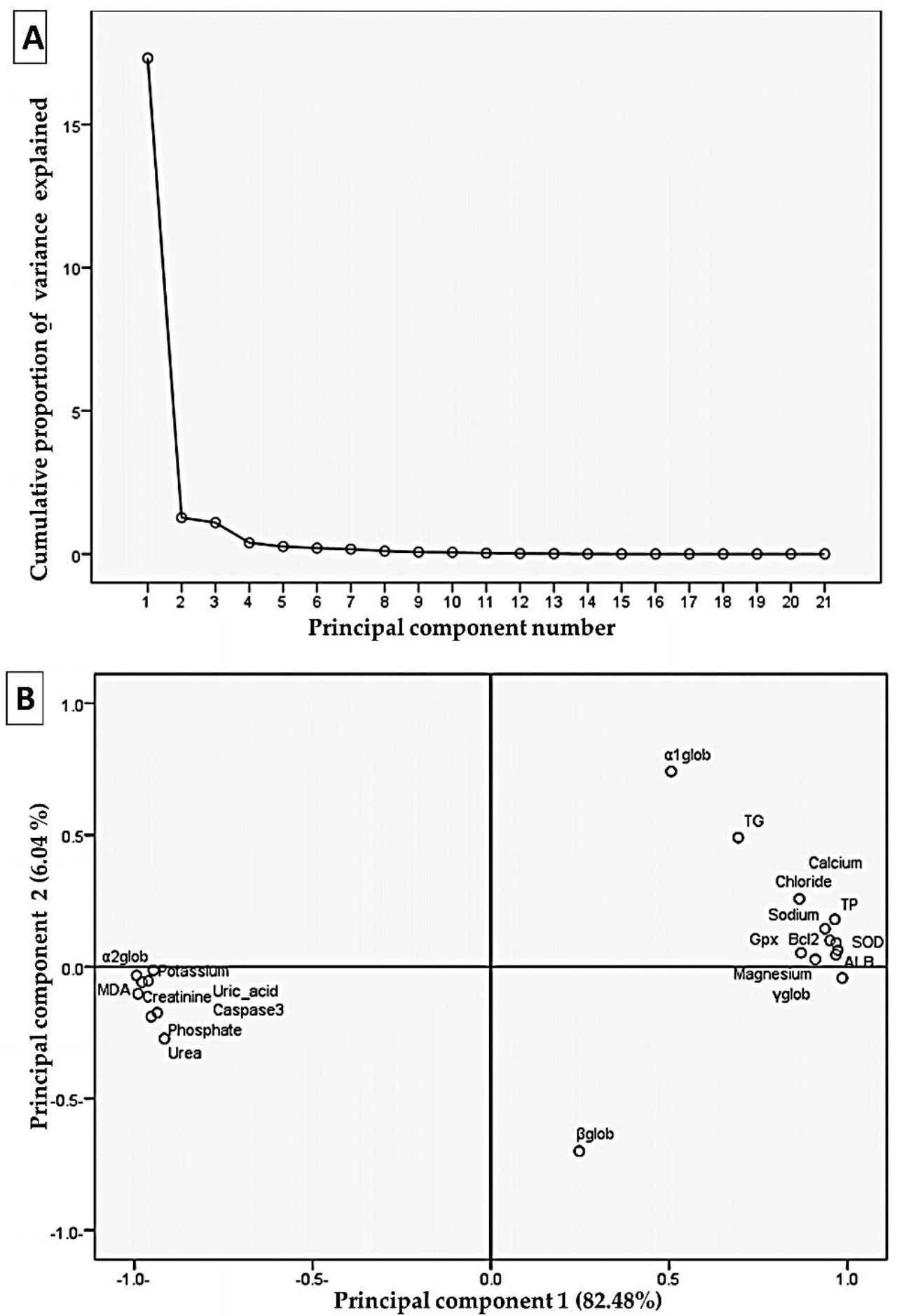

Figure 6. Principal component analysis plot showing the relationships among the estimated variables. (A) Cumulative proportion of variance as a function of the number of principal components (PC). (B) All of the biochemical indicators plotted as a function of PC1 and PC2, which account for $82.48 \%$ and $6.04 \%$ of the variance, respectively. TB: total protein; TG: total globulin; ALB: albumin; Gpx: glutathione peroxidase; SOD: superoxide dismutase; and MDA: malondialdehyde.

\section{Discussion}

Salicylate is the main biotransformation product of aspirin [55], one of the most widely used drugs worldwide [56]. At the same time, CUR is widely consumed worldwide as its global market size is expected to reach USD 151.9 million by 2027 [57]. Thus, the outcomes of the simultaneous application of CUR and aspirin or SS is highly warranted. 
Initially, the current study showed that neither the individual SS injection nor the oral CUR dose alters the erythrogram elements compared to the control groups. However, the combined SS+CUR administration induced an apparent anemic condition. Similarly, CUR has been reported to worsen anemic condition caused by ecstasy in the male rat, while the CUR alone has not elicit any significant changes in the erythrogram elements [29]. This is the first report that shows the synergistic exacerbating effect of CUR with SS on RBCs. CUR has also been shown to inhibit drug-metabolizing cytochrome P450, UDPglucuronosyltransferase, and glutathione-S-transferase [58-61]. The inhibition of such enzymes may result in unwanted increases in the plasma concentrations of certain drugs and may lead to toxicity [61]. Of note, the liver cytochrome's ability to metabolize xenobiotics has been reported to decline with aging $[62,63]$. Additionally, most hepatic cytochrome P450 mRNA expressions are reduced with aging $[64,65]$. Simultaneously, elderly persons extensively use analgesics such as non-steroidal anti-inflammatory drugs and herbal supplements such as CUR $[66,67]$. Thus, more caution should be taken with the co-use of SS with CUR in elderly persons, and further studies on this point are highly warranted. CUR is an active iron Chelator in vivo and induced anemia in mice fed iron-deficient diets [68]. CUR suppresses the synthesis of hepcidin, one of the iron balance peptides, and has the potential to cause iron deficiency in preclinical iron deficiency [68]. CUR binds ferric iron $\left(\mathrm{Fe}^{3+}\right)$ to form dose-dependent CUR and $\mathrm{Fe}^{3+}$ specific composites [69]. This suggests that, particularly in people with iron under optimal conditions, CUR can affect systemic iron metabolism [70].

An obvious thrombocytopenic, leukocytosis, and neutrophilia condition was recorded in SS-injected rats. Similarly, leukocytosis and thrombocytopenia have been previously reported with SS overdose [71]. SS-induced thrombocytopenia could be a consequence of the impaired renal function detected in the SS-injected group [72]. Additionally, neutrophil accumulation may lead to the release of reactive oxygen species (ROS) and may elicit inflammatory responses, which may, in turn, recruit neutrophils [73]. Oppositely, CUR concurrent treatment in SS-injected rats considerably restored the depleted thrombocytes but suppressed the increased leukocytes and neutrophils counts. The CUR antioxidant activity could correct the disturbance of leukocytes and platelet count [74].

Herein, SS substantially increased kidney damage products, including urea, creatinine, and uric acid. Moreover, numerous pathological changes were detected in kidney tissues of SS-injected rats, including vascular congestion, hyalinization of the blood vessel, absence of capsular space, glomerular congestion, coagulative necrosis, congestion of peritubular capillaries, absence of glomerular tuft, tubular dilation, shrinkage of the glomerulus, and vacuolation of the lining epithelium of tubules. Covalent binding of SS or its metabolites with proximal tubular cell mitochondria has been proposed to change these organelles function, thereby interfering with the energy supply $[5,75,76]$. A diminished energy supply in proximal tubular cells can cause active transporter dysfunction or cellular death in more serious conditions [7]. However, a CUR oral dose in SS-injected rats considerably depressed the increases in urea, creatinine, and uric acid and restored normal kidney structure. The protective effect of CUR on kidneys has been evaluated in previous studies with drugs such as gentamicin [77] and cisplatin [78]. This effect can be linked to the antioxidant properties of CUR, since the impairment of the glomerular filter rate may be implied by ROS [79].

In this research, hypoproteinemia, hypoalbuminemia, hypoglobulinemia, and hypo $\gamma$ globulinemia alongside a decreased albumin/globulin ratio were apparent in SS-injected rats. This might be the outcome of a combination of reduced synthesis and increased degradation of albumin [80]. Additionally, earlier reports confirmed the link between increased $\alpha 2$ globulin and nephrotic syndrome [81]. In contrast, CUR mutual co-treatment in SS-injected rats significantly corrected the altered protein profile reflecting enhanced renal function. Additionally, CUR-associated restoration of total protein, albumin, and globulin could be a consequence of liver protection [82].

The kidneys are the main organ for maintaining the equilibrium and acid balance of different electrolytes in the body [83]. A gradual loss of renal function leads to many adapt- 
able and compensatory renal and extrarenal modifications that allow for homeostasis with moderate glomerular filtration rates to be maintained [84]. With the considerable reduction in glomerular filtration rates, there are usually irregularities in the body's environment with clinical consequences [85]. In the current study, SS injection for 15 days induced a clear disturbance in the electrolyte balance represented by hyponatremia, hypochloremia, hypocalcemia, and hypomagnesemia but not hyperkalemia and hypophosphatemia. The overall $\mathrm{Na}$ body content is the key determinant of extracellular volume, and thus, the sodium balance disturbances could lead to clinical conditions of volume depletion or overload [85]. The kidney's ability to excrete $\mathrm{K}$ is reduced proportionally to glomerular filter loss. The use of drugs that alter the kidneys' ability to excrete potassium is the leading cause of hyperkalemia [85]. Despite the increase in K level in the SS-treated group, no mortalities were recorded throughout the experiment. In this regard, the effects of hyperkalemia on ECG in the rat may differ from other species. For instance, an earlier report confirmed that, in rats, $\mathrm{K}$ concentration could reach $10.8 \mathrm{mmol} / \mathrm{L}$ in the blood plasma and returns to normal values within $2 \mathrm{~h}$. [86]. The authors suggested that the redistribution of $\mathrm{K}$ between extra- and intracellular fluid plays a major role in the restoration of $\mathrm{K}$ homeostasis in rats. Additionally, de Araujo, et al. [87] reported that aging rats adapt to extreme conditions of $\mathrm{K}$ deprivation and $\mathrm{K}$ loading. Hypokalemia occurs in most patients with moderate to severe salicylate toxicity until serious dehydration, malfunction of the kidney, or rhabdomyolysis result in hyperkalemia [88]. On the other hand, the CUR+SS-treated group showed a significant correction of the electrolytes levels.

Oxidative stress has been implicated in the pathogenesis of various nephrotoxic drugs [89,90]. Moreover, in numerous renal illnesses, apoptosis is frequently involved [91,92]. Herein, SS substantially increased MDA and Caspase-3 amounts in the kidney tissue but depleted SOD, GPx, and BCL-2. Although SS has well-known antioxidant effects at small doses [93], the SS high doses act as a pro-oxidant that promotes cell death. Earlier in vivo and in vitro reports established the oxidative stress implication as a mechanism of salicylates toxicity [94,95]. Moreover, Deng, et al. [96] suggested that high SS concentrations in vitro have resulted in paradoxical superoxide radical upregulation that produced apoptotic consequences. SS-induced apoptosis has been mediated by the activation of p38 mitogen-activated protein kinases, leading to Caspase- 3 activation [97]. The oxidative, lipid peroxidative, and apoptotic damage induced by SS can elucidate the pathological disturbances detected during the histopathology of the kidney.

Here, the CUR nephroprotective effect could be greatly related to its strong antioxidant and antiapoptotic activity. Similarly, the nephroprotective effect of CUR via restoration of the antioxidant system and lowered lipid peroxidation in the kidneys of rats has been reported [98]. Additionally, CUR treatment inhibited renal tubular cell apoptosis [30,99]. The antioxidant mechanism of CUR proposed can comprise one or more interactions such as free radical scavenging; neutralization of the oxidative cascade interaction; and the prevention and reduction in the amount of scavenging oxidizing enzymes, such as the cytochrome P450 inhibiting [100], oxygen quenching, and disarming properties of toxicants [101].

Furthermore, the antioxidant mechanism of CUR is due to its unique conjugation structure, comprising two methoxylated phenols and an enol diketone that has a typical radical capability as an antioxidant to break down the chains [102]. CUR therapy induces detoxification enzymes ascribed to free radical scavenging and lysosome enzyme liberating inhibition [103]. CUR helps preserve the cell membrane integrity by preventing peroxidation in the presence of toxicants [104].

The ROS ability to signal cell survival or death appears to be related to gene expression regulation via inhibition or activation of redox responsive transcription factors [105,106]. $\mathrm{NF}-\mathrm{KB}$ encompasses an inducible transcription factor family that chiefly regulates host inflammatory and immune responses [107]. Several NF- $\mathrm{kB}$ activation reports have been recorded in the kidney after exposure to many drugs $[108,109]$. Herein, an apparent increase in NF- $\mathrm{kB}$ immuno-expression in the kidney tissue following SS administration was detected 
but suppressed following CUR treatment. In this regard, Hoppstädter, et al. [110] suggested that the CUR anti-inflammatory properties are based on the regulation of transcribed factors, growth factors, signal transduction pathways, and inflammatory cytokines by eliminating the signaling of NF- $\mathrm{KB}$.

One of the most frequently used multivariate statistical tools is principal component analysis because it distinguishes samples from two-dimensional projection [111]. In this context, the loading results show a significant correlation between estimated biomarker responses. The amount of total protein and the indicators of oxidative stress (i.e., SOD and GPx) and apoptosis (i.e., Bcl-2) were strongly correlated with various electrolyte disturbances in sodium, chloride, and calcium. In this line, several studies confirm the interplay of oxidative stress and apoptosis in sequencing events leading to kidney dysfunction $[112,113]$.

\section{Conclusions}

Taken together, the collective findings from the current study propose that the SS use at high doses could be nephrotoxic, as manifested by impaired renal function, impaired electrolyte balance, and histopathological perturbations in kidney tissue. This might be mediated mainly through oxidative damage, apoptotic changes, and inflammatory consequences in the kidney. Despite the evident protective role of CUR against SS-induced renal damage, the combined CUR and SS treatment resulted in a significant anemic condition. Further studies on the combined use of CUR and other analgesic drugs, particularly at large doses, are highly recommended.

Author Contributions: Conceptualization, Y.M.A.-E., A.A.A.M., R.R.B., W.A.M.M., B.A.S., and M.M.E.D.; methodology, Y.M.A.-E., A.A.A.M., R.R.B., W.A.M.M., B.A.S., and M.M.E.D.; software, Y.M.A.-E. and M.M.E.D.; validation, Y.M.A.-E. and R.R.B.; formal analysis, Y.M.A.-E. and W.A.M.M.; investigation, Y.M.A.-E., A.A.A.M., A.A., R.R.B., W.A.M.M., M.M.S., B.A.S., and M.M.E.D.; resources, Y.M.A.-E., A.A.A.M., A.A., R.R.B., W.A.M.M., M.M.S., B.A.S., and M.M.E.D.; data curation, Y.M.A.-E.; writing-original draft preparation, Y.M.A.-E.; writing-review and editing, A.A.A.M., A.A., R.R.B., W.A.M.M., M.M.S., B.A.S., and M.M.E.D.; visualization, Y.M.A.-E. and R.R.B.; project administration, A.A. and M.M.S.; funding acquisition, A.A. and M.M.S. All authors have read and agreed to the published version of the manuscript.

Funding: This study was supported by the Taif University Researchers Supporting Project (TURSP2020/197), Taif University, Taif, Saudi Arabia.

Institutional Review Board Statement: The study was approved by the Institutional Animal Care and Use Committee of Zagazig University, Egypt (ZU-IACUC/2/F/2021).

Informed Consent Statement: Not applicable.

Data Availability Statement: All datasets generated for this study are included in the article.

Acknowledgments: We appreciate and thank Taif University for the financial support for Taif University Researchers Supporting Project (TURSP-2020/197), Taif University, Taif, Saudi Arabia.

Conflicts of Interest: The authors declare no conflict of interest.

\section{References}

1. Wang, H.T.; Luo, B.; Huang, Y.N.; Zhou, K.Q.; Chen, L. Sodium salicylate suppresses serotonin-induced enhancement of GABAergic spontaneous inhibitory postsynaptic currents in rat inferior colliculus in vitro. Hear. Res. 2008, 236, 42-51. [CrossRef] [PubMed]

2. Yin, M.; Xia, C.; Wu, C.; Ji, Y.; Zhou, Y. Aberrant expression of Nav1.6 in the cochlear nucleus correlates with salicylate-induced tinnitus in rats. Biochem. Biophys. Res. Commun. 2020, 526, 786-792. [CrossRef] [PubMed]

3. Wallace, M.N.; Sumner, C.J.; Berger, J.I.; McNaughton, P.A.; Palmer, A.R. Salicylate decreases the spontaneous firing rate of guinea pig auditory nerve fibres. Neurosci. Lett. 2021, 747, 135705. [CrossRef] [PubMed]

4. Abd-Elhakim, Y.M.; Abdel-Motal, S.M.; Malhat, S.M.; Mostafa, H.I.; Moselhy, A.A.; Beheiry, R.R.; Said, E.N. Curcumin mitigates neurotoxic and neurobehavioral changes of gentamicin and sodium salicylate in rats by adjusting oxidative stress and apoptosis. Life Sci. 2021, 265, 118824. [CrossRef] [PubMed] 
5. McMahon, T.F.; Stefanski, S.A.; Wilson, R.E.; Blair, P.C.; Clark, A.-M.; Birnbaum, L.S. Comparative acute nephrotoxicity of salicylic acid, 2, 3-dihydroxybenzoic acid, and 2, 5-dihydroxybenzoic acid in young and middle aged Fischer 344 rats. Toxicology 1991, 66, 297-311. [CrossRef]

6. Casadevall, G.; Moreno, J.; Franch, M.; Queralt, J. N-acetyl-beta-D-glucosaminidase (NAG) and alanine aminopeptidase (AAP) excretion after acute administration of acetaminophen, salsalate and aspirin in rats. Res. Commun. Chem. Pathol. Pharmacol. 1993, $81,77-89$.

7. Tsimihodimos, V.; Psychogios, N.; Kakaidi, V.; Bairaktari, E.; Elisaf, M. Salicylate-induced proximal tubular dysfunction. Am. J. Kidney Dis. 2007, 50, 463-467. [CrossRef]

8. $\quad$ Runde, T.J.; Nappe, T.M. Salicylates Toxicity. In StatPearls; StatPearls Publishing LLC.: Treasure Island, FL, USA, 2021.

9. Mohapatra, T.K.; Moharana, A.K.; Swain, R.P.; Subudhi, B.B. Coamorphisation of acetyl salicylic acid and curcumin for enhancing dissolution, anti-inflammatory effect and minimizing gastro toxicity. J. Drug Deliv. Sci. Technol. 2021, 61, 102119. [CrossRef]

10. Abd-Elhakim, Y.M.; Ghoneim, M.H.; Ebraheim, L.L.; Imam, T.S. Taurine and hesperidin rescues carbon tetrachloride-triggered testicular and kidney damage in rats via modulating oxidative stress and inflammation. Life Sci. 2020, 254, 117782. [CrossRef]

11. Abd-Elhakim, Y.M.; Mohamed, W.A.; Bohi, K.M.E.; Ali, H.A.; Mahmoud, F.A.; Saber, T.M. Prevention of melamine-induced hepatorenal impairment by an ethanolic extract of Moringa oleifera: Changes in KIM-1, TIMP-1, oxidative stress, apoptosis, and inflammation-related genes. Gene 2021, 764, 145083. [CrossRef]

12. Behairy, A.; Mohamed, W.A.; Ebraheim, L.L.; Soliman, M.M.; Abd EL-Hakim, Y.M.; El-Sharkawy, N.I.; Saber, T.M.; El Deib, M.M. Boldenone undecylenate mediated hepatorenal impairment by oxidative damage and dysregulation of heat shock protein 90 and androgen receptors expressions: Vitamin C preventive role. Front. Pharmacol. 2021, 12, 927. [CrossRef] [PubMed]

13. Hashem, M.A.; Shoeeb, S.B.; Abd-Elhakim, Y.M.; Mohamed, W.A. The antitumor activity of Arthrospira platensis and/or cisplatin in a murine model of Ehrlich ascites carcinoma with hematinic and hepato-renal protective action. J. Funct. Foods 2020, 66, 103831. [CrossRef]

14. Aggarwal, B.B.; Harikumar, K.B. Potential therapeutic effects of curcumin, the anti-inflammatory agent, against neurodegenerative, cardiovascular, pulmonary, metabolic, autoimmune and neoplastic diseases. Int. J. Biochem. Cell Biol. 2009, 41, 40-59. [CrossRef] [PubMed]

15. Momtazi, A.A.; Sahebkar, A. Difluorinated Curcumin: A Promising Curcumin Analogue with Improved Anti-Tumor Activity and Pharmacokinetic Profile. Curr. Pharm. Des. 2016, 22, 4386-4397. [CrossRef]

16. Pivari, F.; Mingione, A.; Brasacchio, C.; Soldati, L. Curcumin and Type 2 Diabetes Mellitus: Prevention and Treatment. Nutrients 2019, 11, 1837. [CrossRef] [PubMed]

17. Jalali, M.; Mahmoodi, M.; Mosallanezhad, Z.; Jalali, R.; Imanieh, M.H.; Moosavian, S.P. The effects of curcumin supplementation on liver function, metabolic profile and body composition in patients with non-alcoholic fatty liver disease: A systematic review and meta-analysis of randomized controlled trials. Complement. Ther. Med. 2020, 48, 102283. [CrossRef]

18. Akbari, S.; Kariznavi, E.; Jannati, M.; Elyasi, S.; Tayarani-Najaran, Z. Curcumin as a preventive or therapeutic measure for chemotherapy and radiotherapy induced adverse reaction: A comprehensive review. Food Chem. Toxicol. 2020, 145, 111699. [CrossRef] [PubMed]

19. Biswas, S.K.; McClure, D.; Jimenez, L.A.; Megson, I.L.; Rahman, I. Curcumin induces glutathione biosynthesis and inhibits NF- $к B$ activation and interleukin-8 release in alveolar epithelial cells: Mechanism of free radical scavenging activity. Antioxid. Redox Signal. 2005, 7, 32-41. [CrossRef]

20. Saber, T.M.; Abo-Elmaaty, A.M.A.; Abdel-Ghany, H.M. Curcumin mitigates mancozeb-induced hepatotoxicity and genotoxicity in rats. Ecotoxicol. Environ. Saf. 2019, 183. [CrossRef]

21. Luthra, P.M.; Lal, N. Prospective of curcumin, a pleiotropic signalling molecule from Curcuma longa in the treatment of Glioblastoma. Eur. J. Med. Chem. 2016, 109, 23-35. [CrossRef] [PubMed]

22. Sordillo, L.A.; Sordillo, P.P.; Helson, L. Curcumin for the Treatment of Glioblastoma. Anticancer Res. 2015, 35, 6373-6378. [PubMed]

23. Mollazadeh, H.; Cicero, A.F.G.; Blesso, C.N.; Pirro, M.; Majeed, M.; Sahebkar, A. Immune modulation by curcumin: The role of interleukin-10. Crit. Rev. Food Sci. Nutr. 2019, 59, 89-101. [CrossRef] [PubMed]

24. Bagheri, H.; Ghasemi, F.; Barreto, G.E.; Rafiee, R.; Sathyapalan, T.; Sahebkar, A. Effects of curcumin on mitochondria in neurodegenerative diseases. Biofactors (Oxf. Engl.) 2020, 46, 5-20. [CrossRef] [PubMed]

25. Ali, B.H.; Abdelrahman, A.; Al Suleimani, Y.; Manoj, P.; Ali, H.; Nemmar, A.; Al Za'abi, M. Effect of concomitant treatment of curcumin and melatonin on cisplatin-induced nephrotoxicity in rats. Biomed. Pharmacother. 2020, 131, 110761. [CrossRef] [PubMed]

26. Edrees, N.E.; Galal, A.A.A.; Abdel Monaem, A.R.; Beheiry, R.R.; Metwally, M.M.M. Curcumin alleviates colistin-induced nephrotoxicity and neurotoxicity in rats via attenuation of oxidative stress, inflammation and apoptosis. Chem. Biol. Interact. 2018, 294, 56-64. [CrossRef]

27. Tejo, J. Chapter 45-Curcumin, antioxidant activity, and paracetamol toxicity. In Toxicology; Patel, V.B., Preedy, V.R., Eds.; Academic Press: Cambridge, MA, USA, 2021; pp. 469-477. [CrossRef]

28. Burgos-Morón, E.; Calderón-Montaño, J.M.; Salvador, J.; Robles, A.; López-Lázaro, M. The dark side of curcumin. Int. J. Cancer 2010, 126, 1771-1775. [CrossRef] 
29. Khalaji, N.; Mohammadzadeh, A.; Derag, M.N.G.; Naderi, R.; Hassanlouei, E.A. Combination effect of ecstasy and curcumin on hematological parameters and serum immunoglobulin levels in early and late phase in male rats. Physiol. Pharmacol. 2020, 24, 12-19.

30. Kim, K.S.; Lim, H.-J.; Lim, J.S.; Son, J.Y.; Lee, J.; Lee, B.M.; Chang, S.-C.; Kim, H.S. Curcumin ameliorates cadmium-induced nephrotoxicity in Sprague-Dawley rats. Food Chem. Toxicol. 2018, 114, 34-40. [CrossRef]

31. Abd Allah, E.S.; Gomaa, A.M. Effects of curcumin and captopril on the functions of kidney and nerve in streptozotocin-induced diabetic rats: Role of angiotensin converting enzyme 1. Appl. Physiol. Nutr. Metab. 2015, 40, 1061-1067. [CrossRef] [PubMed]

32. Sun, R.; Chen, W.; Cao, X.; Guo, J.; Wang, J. Protective effect of curcumin on acrylamide-induced hepatic and renal impairment in rats: Involvement of CYP2E1. Nat. Prod. Commun. 2020, 15, 1934578X20910548. [CrossRef]

33. Akintunde, J.; Farouk, A.; Mogbojuri, O. Metabolic treatment of syndrome linked with Parkinson's disease and hypothalamus pituitary gonadal hormones by turmeric curcumin in Bisphenol-A induced neuro-testicular dysfunction of wistar rat. Biochem. Biophys. Rep. 2019, 17, 97-107. [CrossRef]

34. Chen, G.-D.; Kermany, M.H.; D’Elia, A.; Ralli, M.; Tanaka, C.; Bielefeld, E.C.; Ding, D.; Henderson, D.; Salvi, R. Too much of a good thing: Long-term treatment with salicylate strengthens outer hair cell function but impairs auditory neural activity. Hear. Res. 2010, 265, 63-69. [CrossRef] [PubMed]

35. Chyka, P.A.; Erdman, A.R.; Christianson, G.; Wax, P.M.; Booze, L.L.; Manoguerra, A.S.; Martin Caravati, E.; Nelson, L.S.; Olson, K.R.; Cobaugh, D.J. Salicylate poisoning: An evidence-based consensus guideline for out-of-hospital management. Clin. Toxicol. 2007, 45, 95-131. [CrossRef] [PubMed]

36. Yi, B.; Hu, S.; Zuo, C.; Jiao, F.; Lv, J.; Chen, D.; Ma, Y.; Chen, J.; Mei, L.; Wang, X. Effects of long-term salicylate administration on synaptic ultrastructure and metabolic activity in the rat CNS. Sci. Rep. 2016, 6, 1-11. [CrossRef]

37. Coulombe, J.; Favreau, L. A new simple semimicro method for colorimetric determination of urea. Clin. Chem. 1963, 9, 102-108. [CrossRef] [PubMed]

38. Larsen, K. Creatinine assay in the presence of protein with LKB 8600 Reaction Rate Analyser. Clin. Chim. Acta Int. J. Clin. Chem. $1972,38,475$.

39. Barham, D.; Trinder, P. Enzymatic determination of uric acid. Analyst 1972, 97, 142-145. [CrossRef] [PubMed]

40. Hillman, G.; Beyer, G.; Klin, Z. Determination of potassium concentration. Chem. Clin. Biochem. 1967, 5, 93.

41. Henry, R.; Cannon, D.; Winkelman, J. Clinical Chemistry Principles and Techniques, 2nd ed.; Haper and Row: Hagerstown, MD, USA, 1974; pp. 411-421.

42. Tietz, N. Clinical guide to laboratory tests, WB Saunders Company. Phila. USA 1990, 554, 556.

43. Gindler, E.M.; King, J.D. Rapid colorimetric determination of calcium in biologic fluids with methylthymol blue. Am. J. Clin. Pathol. 1972, 58, 376-382. [CrossRef]

44. Schales, O.; Schales, S.S. A simple and accurate method for the determination of chloride in biological fluids. J. Biol. Chem. 1941, 140, 879-882. [CrossRef]

45. El-Merzabani, M.; El-Aaser, A.; Zakhary, N.I. New Method Determ. Inorg. Phosphorus Serum Deproteinization. J. Clin. Chem. Clin. Biochem. 1977, 15, 715-718.

46. Gornal, A.; Bardawill, C.; David, M. Protein-Biuret colorimetric method. J. Biol. Chem. 1949, 177, 751.

47. Doumas, B.T.; Bayse, D.D.; Carter, R.J.; Peters, T.; Schaffer, R. A candidate reference method for determination of total protein in serum. I. Development and validation. Clin. Chem. 1981, 27, 1642-1650. [CrossRef]

48. Doumas, B.; Biggs, H. Determination of Serum Globulin in: Standerd Methods of Clinical Chemistry; Cooper, Ed.; Academic Press: New York, NY, USA, 1972; Volume 7.

49. Ornstein, L. Disc electrophoresis-i background and theory. Ann. N. Y. Acad. Sci. 1964, 121, 321-349. [CrossRef]

50. Nishikimi, M.; Rao, N.A.; Yagi, K. The occurrence of superoxide anion in the reaction of reduced phenazine methosulfate and molecular oxygen. Biochem. Biophys. Res. Commun. 1972, 46, 849-854. [CrossRef]

51. Paglia, D.E.; Valentine, W.N. Studies on the quantitative and qualitative characterization of erythrocyte glutathione peroxidase. $J$. Lab. Clin. Med. 1967, 70, 158-169.

52. Ohkawa, H.; Ohishi, N.; Yagi, K. Assay for lipid peroxides in animal tissues by thiobarbituric acid reaction. Anal. Biochem. 1979, 95, 351-358. [CrossRef]

53. Suvarna, K.S.; Layton, C.; Bancroft, J.D. Bancroft's Theory and Practice of Histological Techniques E-Book; Elsevier Health Sciences: Amsterdam, The Netherlands, 2018.

54. Ramos-Vara, J.A.; Kiupel, M.; Baszler, T.; Bliven, L.; Brodersen, B.; Chelack, B.; West, K.; Czub, S.; Del Piero, F.; Dial, S. Suggested guidelines for immunohistochemical techniques in veterinary diagnostic laboratories. J. Vet. Diagn. Investig. 2008, $20,393-413$. [CrossRef] [PubMed]

55. Amann, R.; Peskar, B.A. Anti-inflammatory effects of aspirin and sodium salicylate. Eur. J. Pharm. 2002, 447, 1-9. [CrossRef]

56. Angiolillo, D.J.; Capodanno, D. Aspirin for Primary Prevention of Cardiovascular Disease in the 21st Century: A Review of the Evidence. Am. J. Cardiol. 2021, 144, S15-S22. [CrossRef] [PubMed] 
57. Curcumin Market Size, Share \& Trends Analysis Report By Application (Pharmaceutical, Food, Cosmetics), By Region (North America, Europe, Asia Pacific, Central \& South America, Middle East \& Africa), And Segment Forecasts, 2020-2027. 2020. Available online: https://www.grandviewresearch.com/industry-analysis/turmeric-extract-curcumin-market?utm_source= pressrelease\&utm_medium=referral\&utm_campaign=PRN_Sep03_Curcumin_RD2\&utm_content=Content (accessed on 17 May 2021).

58. Oetari, S.; Sudibyo, M.; Commandeur, J.N.; Samhoedi, R.; Vermeulen, N.P. Effects of curcumin on cytochrome P450 and glutathione S-transferase activities in rat liver. Biochem. Pharmacol. 1996, 51, 39-45. [CrossRef]

59. Appiah-Opong, R.; Commandeur, J.N.; van Vugt-Lussenburg, B.; Vermeulen, N.P. Inhibition of human recombinant cytochrome P450s by curcumin and curcumin decomposition products. Toxicology 2007, 235, 83-91. [CrossRef] [PubMed]

60. Thapliyal, R.; Maru, G. Inhibition of cytochrome P450 isozymes by curcumins in vitro and in vivo. Food Chem. Toxicol. 2001, 39, 541-547. [CrossRef]

61. Mancuso, C.; Barone, E. Curcumin in clinical practice: Myth or reality? Update 2009, 30, 333-334. [CrossRef] [PubMed]

62. Salmin, S.F.; Giroux, M.C.; Vachon, P.; Beaudry, F. In vitro metabolism of specific CYP2D and CYP3A opioid substrates using rat liver S9 fractions and mass spectrometry reveal a severe metabolic impairment with increasing age. Biomed. Chromatogr. 2017, 31. [CrossRef]

63. Wauthier, V.; Verbeeck, R.-K.; Buc Calderon, P. The effect of ageing on cytochrome p450 enzymes: Consequences for drug biotransformation in the elderly. Curr. Med. Chem. 2007, 14, 745-757. [CrossRef]

64. Mori, K.; Blackshear, P.E.; Lobenhofer, E.K.; Parker, J.S.; Orzech, D.P.; Roycroft, J.H.; Walker, K.L.; Johnson, K.A.; Marsh, T.A.; Irwin, R.D. Hepatic transcript levels for genes coding for enzymes associated with xenobiotic metabolism are altered with age. Toxicol. Pathol. 2007, 35, 242-251. [CrossRef]

65. Xu, S.-F.; Hu, A.-L.; Xie, L.; Liu, J.-J.; Wu, Q.; Liu, J. Age-associated changes of cytochrome P450 and related phase-2 gene/proteins in livers of rats. PeerJ 2019, 7, e7429. [CrossRef]

66. Ingrasciotta, Y.; Sultana, J.; Giorgianni, F.; Menditto, E.; Scuteri, A.; Tari, M.; Tari, D.U.; Basile, G.; Trifiro, G. Analgesic drug use in elderly persons: A population-based study in Southern Italy. PLoS ONE 2019, 14, e0222836. [CrossRef]

67. Silva, J.; Souza, C.; Silva, T.; Gomes, I.; Brito, G.; Araújo, A.; Lyra Jr, D.; Silva, W.; Silva, F. Use of Herbal Medicines by Elderly Patients: A Systematic Review. Arch. Gerontol. Geriatr. 2014, 59. [CrossRef]

68. Jiao, Y.; Wilkinson IV, J.; Di, X.; Wang, W.; Hatcher, H.; Kock, N.D.; D'Agostino Jr, R.; Knovich, M.A.; Torti, F.M.; Torti, S.V. Curcumin, a cancer chemopreventive and chemotherapeutic agent, is a biologically active iron chelator. Blood J. Am. Soc. Hematol. 2009, 113, 462-469. [CrossRef] [PubMed]

69. Srichairatanakool, S.; Thephinlap, C.; Phisalaphong, C.; Porter, J.; Fucharoen, S. Curcumin contributes to in vitro removal of non-transferrin bound iron by deferiprone and desferrioxamine in thalassemic plasma. Med. Chem. 2007, 3, 469-474. [CrossRef]

70. Means Jr, R.T. Ironing out complementary medicine. Blood J. Am. Soc. Hematol. 2009, 113, 270-271. [CrossRef]

71. Ciejka, M.; Nguyen, K.; Bluth, M.H.; Dubey, E. Drug toxicities of common analgesic medications in the emergency department. Clin. Lab. Med. 2016, 36, 761-776. [CrossRef]

72. Dorgalaleh, A.; Mahmudi, M.; Tabibian, S.; Khatib, Z.K.; Tamaddon, G.H.; Moghaddam, E.S.; Bamedi, T.; Alizadeh, S.; Moradi, E. Anemia and thrombocytopenia in acute and chronic renal failure. Int. J. Hematol. Oncol. Stem Cell Res. 2013, 7, 34-39.

73. Mittal, M.; Siddiqui, M.R.; Tran, K.; Reddy, S.P.; Malik, A.B. Reactive oxygen species in inflammation and tissue injury. Antioxid. Redox Signal. 2014, 20, 1126-1167. [CrossRef]

74. Khalaji, N.; Dindarian, S.; Hazeghi-Rad, A.A.; Baba Hasanzadeh, S.; Asghari, S. The Role of Curcumin on Reduced Leukocyte and Platelet Counts in Rats After Exposure to Ultraviolet Light from Compact Fluorescent Lamps: A Morphological Study. Shiraz E Med. J. 2019, 20, e85196. [CrossRef]

75. Kyle, M.E.; Kocsis, J.J. The effect of age on salicylate-induced nephrotoxicity in male rats. Toxicol. Appl. Pharmacol. 1985, 81, 337-347. [CrossRef]

76. Kyle, M.E.; Kocsis, J.J. The effect of mixed function oxidase induction and inhibition on salicylate-induced nephrotoxicity in male rats. Toxicol. Appl. Pharmacol. 1986, 84, 241-249. [CrossRef]

77. Manikandan, R.; Beulaja, M.; Thiagarajan, R.; Priyadarsini, A.; Saravanan, R.; Arumugam, M. Ameliorative effects of curcumin against renal injuries mediated by inducible nitric oxide synthase and nuclear factor kappa $\mathrm{B}$ during gentamicin-induced toxicity in Wistar rats. Eur. J. Pharmacol. 2011, 670, 578-585. [CrossRef]

78. Ueki, M.; Ueno, M.; Morishita, J.; Maekawa, N. Curcumin ameliorates cisplatin-induced nephrotoxicity by inhibiting renal inflammation in mice. J. Biosci. Bioeng. 2013, 115, 547-551. [CrossRef]

79. Hughes, A.K.; Stricklett, P.K.; Padilla, E.; Kohan, D.E. Effect of reactive oxygen species on endothelin-1 production by human mesangial cells. Kidney Int. 1996, 49, 181-189. [CrossRef] [PubMed]

80. Haller, C. Hypoalbuminemia in renal failure: Pathogenesis and therapeutic considerations. Kidney Blood Press. Res. 2005, 28, 307-310. [CrossRef] [PubMed]

81. O'Connell, T.; Horita, T.J.; Kasravi, B. Understanding and interpreting the serum protein electrophoresis. Am. Fam. Physician 2005, 71, 105-112. [PubMed]

82. Yousef, M.I.; Omar, S.A.; El-Guendi, M.I.; Abdelmegid, L.A. Potential protective effects of quercetin and curcumin on paracetamolinduced histological changes, oxidative stress, impaired liver and kidney functions and haematotoxicity in rat. Food Chem. Toxicol. 2010, 48, 3246-3261. [CrossRef] 
83. Ellison, D.; Farrar, F.C. Kidney Influence on Fluid and Electrolyte Balance. Nurs. Clin. N. Am. 2018, 53, 469-480. [CrossRef] [PubMed]

84. Inker, L.A.; Perrone, R.D. Assessment of Kidney Function. 2014. Available online: https://www.uptodate.com/contents/ assessment-of-kidney-function (accessed on 17 May 2021).

85. Arroyo, R.A. Electrolyte and acid-base balance disorders in advanced chronic kidney disease. Nefrol. Publ. Off. Soc. Esp. Nefrol. 2008, 28, 87-93.

86. Sokolova, M.; Leont'ev, V.; Semenova, O.; Khrustaleva, R. Potassium distribution in rat tissues in relation to its concentration in the blood. Fiziol. Zhurnal SSSR Im. IM Sechenova 1990, 76, 1557-1562.

87. de Araujo, M.; Helou, C.M.d.B.; Seguro, A.C. Renal potassium handling in aging rats. Kidney Blood Press. Res. 1998, $21,425-431$. [CrossRef] [PubMed]

88. Curry, S.C.; Spyres, M.B. Salicylates. In Critical Care Toxicology: Diagnosis and Management of the Critically Poisoned Patient; Brent, J., Burkhart, K., Dargan, P., Hatten, B., Megarbane, B., Palmer, R., White, J., Eds.; Springer International Publishing: Cham, Switzerland, 2017; pp. 1251-1267.

89. Un, H.; Ugan, R.A.; Gurbuz, M.A.; Bayir, Y.; Kahramanlar, A.; Kaya, G.; Cadirci, E.; Halici, Z. Phloretin and phloridzin guard against cisplatin-induced nephrotoxicity in mice through inhibiting oxidative stress and inflammation. Life Sci. 2021, 266, 118869. [CrossRef] [PubMed]

90. Vysakh, A.; Abhilash, S.; Kuriakose, J.; Midhun, S.J.; Jyothis, M.; Latha, M.S. Protective effect of Rotula aquatica Lour against gentamicin induced oxidative stress and nephrotoxicity in Wistar rats. Biomed. Pharmacother. 2018, 106, 1188-1194. [CrossRef]

91. Alshahrani, S.; Ashafaq, M.; Hussain, S.; Mohammed, M.; Sultan, M.; Jali, A.M.; Siddiqui, R.; Islam, F. Renoprotective effects of cinnamon oil against APAP-Induced nephrotoxicity by ameliorating oxidative stress, apoptosis and inflammation in rats. Saudi Pharm. J. 2021, 29, 194-200. [CrossRef] [PubMed]

92. Rafiee, Z.; Moaiedi, M.Z.; Gorji, A.V.; Mansouri, E. P-Coumaric acid mitigates doxorubicin-induced nephrotoxicity through suppression of oxidative stress, inflammation and apoptosis. Arch. Med. Res. 2020, 51, 32-40. [CrossRef] [PubMed]

93. Yiannakopoulou, E.C.; Tiligada, E. Protective effect of salicylates against hydrogen peroxide stress in yeast. J. Appl. Microbiol. 2009, 106, 903-908. [CrossRef]

94. Mohamed, W.A.; Abd-Elhakim, Y.M.; Ismail, S.A. Involvement of the anti-inflammatory, anti-apoptotic, and anti-secretory activity of bee venom in its therapeutic effects on acetylsalicylic acid-induced gastric ulceration in rats. Toxicology 2019, 419, 11-23. [CrossRef]

95. Seo, M.S.; Oh, S.Y.; Park, M.J.; Kim, S.M.; Kim, M.Y.; Han, S.I.; Park, H.G.; Kang, H.S. Implication of reactive oxygen species, ERK1/2, and p38MAPK in sodium salicylate-induced heat shock protein 72 expression in C6 glioma cells. Int. J. Mol. Med. 2005, 16, 841-849. [CrossRef]

96. Deng, L.; Ding, D.; Su, J.; Manohar, S.; Salvi, R. Salicylate selectively kills cochlear spiral ganglion neurons by paradoxically up-regulating superoxide. Neurotox. Res. 2013, 24, 307-319. [CrossRef]

97. Lee, E.J.; Park, H.G.; Kang, H.S. Sodium salicylate induces apoptosis in HCT116 colorectal cancer cells through activation of p38MAPK. Int. J. Oncol. 2003, 23, 503-508. [CrossRef]

98. Tokaç, M.; Taner, G.; Aydın, S.; Özkardeş, A.B.; Dündar, H.Z.; Taşlıpınar, M.Y.; Arıkök, A.T.; Kılıç, M.; Başaran, A.A.; Basaran, N. Protective effects of curcumin against oxidative stress parameters and DNA damage in the livers and kidneys of rats with biliary obstruction. Food Chem. Toxicol. 2013, 61, 28-35. [CrossRef]

99. Topcu-Tarladacalisir, Y.; Sapmaz-Metin, M.; Karaca, T. Curcumin counteracts cisplatin-induced nephrotoxicity by preventing renal tubular cell apoptosis. Ren. Fail. 2016, 38, 1741-1748. [CrossRef] [PubMed]

100. Unnikrishnan, M.; Rao, M. Curcumin inhibits nitrogen dioxide induced oxidation of hemoglobin. Mol. Cell. Biochem. 1995, 146, 35-37. [CrossRef] [PubMed]

101. Rao, M. Curcuminoids as potent inhibitors of lipid peroxidation. J. Pharm. Pharmacol. 1994, 46, 1013-1016.

102. Masuda, T.; Maekawa, T.; Hidaka, K.; Bando, H.; Takeda, Y.; Yamaguchi, H. Chemical studies on antioxidant mechanism of curcumin: Analysis of oxidative coupling products from curcumin and linoleate. J. Agric. Food Chem. 2001, 49, $2539-2547$. [CrossRef]

103. Manikandan, P.; Sumitra, M.; Aishwarya, S.; Manohar, B.M.; Lokanadam, B.; Puvanakrishnan, R. Curcumin modulates free radical quenching in myocardial ischaemia in rats. Int. J. Biochem. Cell Biol. 2004, 36, 1967-1980. [CrossRef]

104. Sankar, P.; Telang, A.G.; Manimaran, A. Protective effect of curcumin on cypermethrin-induced oxidative stress in Wistar rats. Exp. Toxicol. Pathol. 2012, 64, 487-493. [CrossRef]

105. Droge, W. Free radicals in the physiological control of cell function. Physiol. Rev. 2002, 82, 47-95. [CrossRef]

106. Bowie, A.; $\mathrm{O}^{\prime}$ Neill, L.A. Oxidative stress and nuclear factor- $\mathrm{kB}$ activation: A reassessment of the evidence in the light of recent discoveries. Biochem. Pharmacol. 2000, 59, 13-23. [CrossRef]

107. Yamamoto, H.; Omelchenko, I.; Shi, X.; Nuttall, A.L. The influence of NF-kB signal-transduction pathways on the murine inner ear by acoustic overstimulation. J. Neurosci. Res. 2009, 87, 1832-1840. [CrossRef]

108. Chauhan, P.; Sharma, H.; Kumar, U.; Mayachari, A.; Sangli, G.; Singh, S. Protective effects of Glycyrrhiza glabra supplementation against methotrexate-induced hepato-renal damage in rats: An experimental approach. J. Ethnopharmacol. 2020, $263,113209$. [CrossRef] 
109. Ramamoorthy, H.; Abraham, P.; Isaac, B.; Selvakumar, D. Role for NF-kB inflammatory signalling pathway in tenofovir disoproxil fumarate (TDF) induced renal damage in rats. Food Chem. Toxicol. 2017, 99, 103-118. [CrossRef] [PubMed]

110. Hoppstädter, J.; Hachenthal, N.; Valbuena-Perez, J.V.; Lampe, S.; Astanina, K.; Kunze, M.M.; Bruscoli, S.; Riccardi, C.; Schmid T.; Diesel, B. Induction of glucocorticoid-induced leucine zipper (GILZ) contributes to anti-inflammatory effects of the natural product curcumin in macrophages. J. Biol. Chem. 2016, 291, 22949-22960. [CrossRef] [PubMed]

111. Granato, D.; Santos, J.S.; Escher, G.B.; Ferreira, B.L.; Maggio, R.M. Use of principal component analysis (PCA) and hierarchical cluster analysis (HCA) for multivariate association between bioactive compounds and functional properties in foods: A critical perspective. Trends Food Sci. Technol. 2018, 72, 83-90. [CrossRef]

112. Salama, M.E.; Adel, M.; Helal, G.; El-Shafey, M. Role of Oxidative Stress, Apoptosis and Autophagy in Cadmium-induced Renal Injury in Rats: Renoprotective Effect of Ghrelin. Bull. Egypt. Soc. Physiol. Sci. 2019, 39, 271-285. [CrossRef]

113. Kaushal, G.P.; Chandrashekar, K.; Juncos, L.A. Molecular Interactions Between Reactive Oxygen Species and Autophagy in Kidney Disease. Int. J. Mol. Sci. 2019, 20, 3791. [CrossRef] [PubMed] 